\title{
Workshop Terapi Seni Ekspresif Pada Anak Pasien Kanker di Rumah Singgah Ykaki Bandung
}

\author{
Shirly Nathania Suhanjoyo, Yunita Setyoningrum, Amanda Muliati \\ Program Studi Sarjana Desain Interior Universitas Kristen Maranatha \\ e-mail: yunita.setyoningrum@art.maranatha.edu
}

Received: 24 March 2021; Revised: 26 June 2021; Accepted: 28 July 2021

DOI: $\underline{\text { http://dx.doi.org/10.37905/aksara.7.3.821-832.2021 }}$

\begin{abstract}
Abstrak
Kegiatan seni terbukti bermanfaat terapi psikologis yang mendorong anak untuk berimajinasi ke arah yang positif. Sebuah serial workshop terapi seni ekspresif dilaksanakan kepada anak-anak pasien kanker di rumah singgah YKAKI Bandung. Kegiatan ini diintegrasikan dengan kegiatan lainnya, seperti olah tubuh, musik dan tari. Tujuannya untuk merangsang spontanitas berekspresi kreatif melalui kegiatan seni yang interaktif dan terapeutik. Program kegiatan seni rupa ini dapat membantu mereduksi stress pada anak pasien kanker. Dalam prosesnya pasien anak kanker diajak menciptakan narasi positif, bercerita dan berimajinasi tentang keberadaan mereka saat ini dan membuat karya berdasarkan narasi tersebut. Pada akhir sessi, karya kreatif mereka dipamerkan kepada publik sebagai wujud dari pencapaian.
\end{abstract}

Kata kunci: terapi seni, ekspresi, psikososial, narasi

\begin{abstract}
Art activities have been proven effective as psychological therapies that stimulate children imagination in a positive way. A series of expressive art therapy workshops was conductedon children with cancer, who were temporarily stayed at Rumah Singgah YKAKI Bandung. The activities were integrated with fitness, music and dance. The aim was to stimulate the creative expression and spontaneity in children through the interactive and therapeutic art activities. The programwas expected to help reduce stress on children with cancer. Cancer patients were invited to create positive narratives, tell stories and imagine their current whereabouts also created works based on these narratives. At the end, their creative workswere exhibited to public as a form of achievement.
\end{abstract}

Keywords: art therapy, expression, psychosocial, narration

\section{PENDAHULUAN}

Kegiatan workshop terapi seni ekspresif ini dilatarbelakangi oleh kenyataan bahwa seni sebagai bagian dari kegiatan bermain dapat dimanfaatkan sebagai media pembelajaran yang efektif. Melalui kegiatan seni, dapat dibentuk karakter-karakter positif pada anak, terutama untuk pendidikan pra-sekolah (PAUD) dan Sekolah Dasar. Dengan memanfaatkan pendekatan seni rupa, anak dapat berekspresi secara kreatif dengan ekspresi artistik yang spontan. Hal ini mendukung tumbuh kembang mental dan 
psikologis anak. Lanier (1969) menyatakan bahwa pendidikan seni penting dalam pendidikan anak karena: 1) memberikan kontribusi terhadap perkembangan individu, 2) memberikan pengalaman yang berharga (pengalaman estetik), 3) sebagai bagian yang penting dari kebudayaan (Loita, 2017). Periode usia dini dalam kehidupan manusia dikatakan sebagai ini periode "the golden age of creative expression", sehingga perlu dimanfaatkan membina dan mengembangkan pola berpikir kreatif pada anak didik. Dalam prakteknya, kegiatan seni rupa untuk anak-anak dianjurkan untuk mengutamakan kebebasan berkarya dengan berbagai media dan metode. Kegiatan ini dapat pula diintegrasikan dengan kegiatan lainnya, seperti sains, olah tubuh, musik dan tari, dan sebagainya. Bahkan melalui kegiatan seni juga dapat dilakukan terapi psikologis yang mendorong anak untuk berimajinasi ke arah yang positif. Hal yang terpenting adalah merangsang spontanitas berekspresi kreatif pada anak. Spontanitas berekspresi-kreatif pada anak hanya terjadi jika didukung oleh iklim yang menunjang dan melalui serangkaian pengalaman berkesenian, baik dalam bentuk kegiatan apresiasi maupun kreasi.

Wachowiak dan Clements (1993) menyatakan bahwa strategi yang penting diperhatikan dalam kegiatan seni untuk pengembangan pola pikir kreatif adalah dengan melakukan stimulasi atau insentif, membangunkan pengalaman pribadi (ingatan, asosiasi emosional), pengamatan langsung kepada objek di lingkungan, asosiasi gagasan dengan bahan/media dan perluasan pengetahuan (Robert D. Clements, Frank Wachowiak, 2010). Permasalahannya, anak-anak pasien kanker sedang menjalani pengobatan, umumnya merasa kurang nyaman saat terpaksa beradaptasi dengan lingkungan yang baru dan rutinitas yang baru. Kegiatan menggambar yang terintegrasi dengan kegiatan kreatif lainnya seperti menyanyi, menari, dan bermain drama juga dapat membantu mengomunikasikan perasaan dan tekanan psikologis anak penderita kanker. Karena kreativitas adalah sesuatu yang kita miliki sejak lahir, maka terlibat dalam ekspresi kreatif adalah cara yang ampuh untuk mendorong penemuan, penyembuhan, dan pertumbuhan diri. Seseorang tidak harus menjadi seniman untuk menjadi kreatif atau terlibat dalam terapi seni ekspresif. Hal-hal sederhana seperti menggambar menggunakan pastel, cat, gerakan, dan suara untuk mengekspresikan apa yang saat ini terlalu membingungkan atau berlebihan untuk diungkapkan dengan kata-kata. Gambar yang dihasilkan anak-anak yang belum fasih menggambar pun sesungguhnya mampu menawarkan cara baru untuk "melihat" atau mengalami situasi.

Beberapa referensi dari penelitian terdahulu menyatakan bahwa kegiatan seni yang dilakukan secara ekspresif dapat berfungsi terapeutik dan berdampak positif bagi kesehatan psikologis pasien kanker. Terapi seni dapat membantu mengurangi kecemasan, depresi, dan nyeri fisik pada pasien, dan sebagian besar pasien juga melaporkan peningkatan umum dalam kualitas hidup mereka. Selain itu, manfaat psikologis hanya bertahan hanya selama terapi, namun demikian setelahnya terdapat indikasi pengurangan rasa sakit pada pasien. Penelitian lainnya menunjukkan bahwa terdapat penurunan gejala kecemasan dan depresi dalam durasi waktu yang lebih panjang (Bozcuk et al., 2017).

Kegiatan seni terapeutik yang dilakukan pada pasien kanker dapat memberi dampak positif dalam hal: a) sebagai sarana ekspresi untuk melepaskan emosi tersembunyi yang tak dapat terkatakan dalam kehidupan sehari-hari, b) berfungsi untuk meningkatkan rasa pengendalian diri sehingga berdampak pada kekuatan diri sendiri, c) dalam prosesnya dapat dikemas metode naratif yang memungkinkan interaksi sosial dengan orang lain 
(mentor, keluarga, terapis), sehingga pasien merasa ditemani dan didengarkan (Singh, 2011). Reynolds dan Lim (2007) menyatakan bahwa hal yang penting dalam kegiatan terapi seni adalah praktik kontinuitas atau keberlanjutan (continuity), adanya tantangan (challenge), dan target pencapaian (achievement) (Reynolds \& Lim, 2007). Bertolak dari argumentasi tersebut di atas, kegiatan workshop Eksperimen Kreatif bagi anak-anak pasien kanker dinisiasikepada anak-anak penderita kanker di Rumah Singgah YKAKI, Jalan Taman Curie no. 23, Bandung. Kegiatan workshop ini dilakukan dalam durasi 3 jam, yang terdiri dari kegiatan eksperimen untuk menggugah pengalaman artistik anak dan penyuluhan kepada guru dan orangtua. Tujuan yang hendak dicapai dari kegiatan ini adalah: diharapkan dapat menjadi kegiatan penyegaran (refreshment) sehingga membantu mereduksi stress pada anak-anak pasien kanker.

\section{METODE}

Kegiatan workshop ini memiliki tiga konsep utama dalam pelaksanaannya yaitu: a) mewujudkan kontinuitas atau keberlanjutan (continuity), walaupun singkat, melalui kegiatan dilakukan secara bertahap dalam 3 sessi; b) mewujudkan tantangan (challenge) melalui proses menciptakan narasi positif, bercerita dan berimajinasi tentang keberadaan mereka saat ini dan membuat karya berdasarkan narasi tersebut; c) mewujudkan pencapaian (achievement), melalui pameran karya pada akhir sessi. Berikut ini uraian deskriptif untuk metode setiap sesi:

\section{Sesi 1 “Keberadaanku Saat Ini: Lingkungan Rumah Singgah YKAKI”}

Strategi yang penting diperhatikan dalam kegiatan seni untuk pengembangan pola pikir kreatif adalah dengan melakukan stimulasi atau insentif, membangunkan pengalaman pribadi (ingatan, asosiasi emosional), pengamatan langsung kepada objek di lingkungan, asosiasi gagasan dengan bahan/media dan perluasan pengetahuan. Karena kreativitas adalah sesuatu yang kita miliki sejak lahir, maka terlibat dalam ekspresi kreatif adalah cara yang ampuh untuk mendorong penemuan, penyembuhan, dan pertumbuhan diri. Seseorang tidak harus menjadi seniman untuk menjadi kreatif atau terlibat dalam terapi seni ekspresif. Berangkat dari pernyataan tersebut, pada kegiatan pertama terapi seni ekspresif, anak didorong untuk menciptakan narasi awal tentang dirinya saat ini dan keberadaannya di rumah singgah. Manfaat kegiatan ini adalah mewujudkan tantangan (challenge) melalui proses menciptakan narasi positif, bercerita dan berimajinasi tentang keberadaan mereka saat ini dan membuat karya berdasarkan narasi tersebut (Robert D. Clements, Frank Wachowiak, 2010).

Teknik kreasi yang diharapkan adalah membuat karya dua dimensional (drawing) pensil, drawing pen, cat air, lem, gunting, pada format kertas ukuran 50x50 cm dengan menggunakan cat air dan dikombinasikan dengan kolase objek-objek yang familiar dengan anak. Kegiatan membuat karya dilaksanakan selama 1-1,5 jam, dilanjutkan dengan kegiatan presentasi (story telling) selama 0,5-1 jam. Komponen kegiatan yang dibutuhkan adalah: a) Meja dan kursi kelompok, b) Team mentor sebagai fasilitator, c) Anak-anak, sebagai creator dan narrator, d) Penonton (audience), memberikan dukungan / feedback. Pada sessi ini dapat melibatkan keluarga dan orangtua. Langkah-langkah pengerjaan adalah sebagai berikut: a) Anak-anak diminta untuk duduk berkelompok sesuai dengan kelompok usia agar memudahkan cara berkomunikasi, b) Team mentor 
akan memberikan contoh video dari youtube mengenai gambar ruangan pada rumah tinggal, bagian-bagiannya (atap, lantai, dinding, pagar, dan sebagainya), c) Team mentor akan membagikan kertas berukuran $50 \times 50 \mathrm{~cm}$ dengan grid garis bantu berbentuk kotak dan lingkaran konsentris. Lalu team mentor akan meminta masing-masing anak untuk menggambarkan rumah singgah secara sederhana, d) Selanjutnya anak diminta untuk menggambarkan diri mereka sendiri (dengan mengeksplorasi identitas visual/karakter fisik diri yang khas), menggambarkan orang lain yang terdekat dengan mereka saat ini (bisa siapa saja), menggambarkan orang-orang di sekitar rumah singgah yang dikenal dan berkesan bagi mereka, e) Gambar orang-orang ini dibuat pada kertas berbeda yang kemudian akan digunting dan ditempelkan seperti kolase pada gambar rumah singgah yang sebelumnya telah dibuat pada kertas berukuran 50x50 cm, f) Selanjutnya anak diminta bercerita tentang kejadian menyenangkan apa saja yang terjadi dengan melibatkan orang-orang yang dibuat dalam kolase. Alat ukur ketercapaian dari kegiatan sesi 1 ini adalah: a) anak merasa relaks dalam berkreasi gambar, b) anak mampu menggambarkan keadaan rumah singgah tempat mereka tinggal sekarang sebagai luapan ekspresi mereka dan c) anak mampu menceritakan apa perasaan terhadap apa yang telah digambar. Adapun gambar tidak harus bagus, teratur, atau indah, namun dalam prosesnya anak dapat bercerita hal-hal yang berkesan atau sebaliknya kurang berkesan bagi mereka.

\section{Sesi 2. Gambar "Harapan Di Hari Spesialku”}

Tujuan kegiatan: Anak memperlihatkan dirinya pada saat ini dan di masa yang datang (tahun depan) melalui gambar bercerita sebagai sarana ekspresi untuk melepaskan emosi tersembunyi yang tak dapat terkatakan dalam kehidupan sehari-hari. Manfaat kegiatan adalah aktivitas mewujudkan tantangan (challenge) melalui proses menciptakan narasi positif, bercerita dan berimajinasi tentang keberadaan mereka saat ini dan membuat karya berdasarkan narasi tersebut.

Teknik kreasi yang diharapkan adalah membuat dua gambar yaitu 1 buah drawing ekspresif tematik dan 1 buah gambar tema bebas sesuai dengan keinginan dan ide anak. Gambar dibuat dengan kertas gambar, pensil, pensil warna, spidol warna yang dilaksanakan dalam waktu 1 jam, kemudian dilanjutkan dengan sesi presentasi dan storytelling (narasi). Komponen kegiatan yang dibutuhkan adalah: a) Meja dan kursi kelompok, b) Team mentor sebagai fasilitator, c) Anak-anak, sebagai creator dan narrator, d) Penonton (audience), memberikan dukungan/feedback. Pada sessi ini dapat melibatkan keluarga dan orangtua. Langkah-langkah pengerjaan adalah sebagai berikut: a) Anakanak diminta duduk berkelompok, dan diberikan sejumlah alat gambar, lalu team mentor akan memberikan pengarahan gambar, yaitu membuat gambar diri (saat ini), b) Anakanak akan menggambar diri mereka sendiri dengan bebas ataupun dibantu oleh team mentor apabila diperlukan, c) Selanjutnya, team mentor memberikan pengarahan untuk membuat gambar kedua (pada kertas yang baru), yaitu gambar diri di satum omen pada tahun depan/di waktu terdekat, contohnya Natal, Idul Fitri, hari ulang tahun, d) Anakanak membuat gambar diri yang menceritakan dirinya pada momen tersebut, e) Selanjutnya, pada saat proses menggambar atau setelah gambar selesai, team mentor akan meminta anak untuk bercerita tentang gambar tersebut (dengan contoh cerita tentang anak sedang apa pada gambar tersebut, dengan siapa, di mana) Pada proses menggambar ini, anak-anak dapat duduk dengan bebas, mengambil posisi yang nyaman dan mendapatkan 
sejumlah kertas beserta alat gambar.Anak dapat memilih pensil, pensil warna, spidol warna yang diiinginkan. Selanjutnya anak-anak diberi kebebasan untuk menggambar apapun yang mereka mau. Team mentor tidak akan memberikan arahan mengenai gambar apa yang harus ditampilkan, sehingga gambar diperbolehkan apapun, termasuk gambar abstrak.

\section{Sesi ke-3: Peran Imajinatif (Psikodrama) "Cita-Citaku”}

Sesi ke-3 dikemas sebagai kegiatan psikodrama. J. L. Moreno menyebutkan bahwa psikodrama adalah salah satu cara untuk mengembangkan potensi manusia melalui eksplorasi tindakan dramatis, masalah, isu, keprihatinan, mimpi dan cita-cita seseorang atau kelompok. Umumnya psikodrama dilakukan secara berkelompok, di mana setiap orang dapat menjadi agen penyembuhan yang dapat membongkar emosi-emosi terpendam antar satu sama lain di dalam kelompok (Alysa Stivanie Kania Damanik, 2015). Psikodrama merupakan permainan peranan yang dimaksudkan agar individu yang bersangkutan dapat memperoleh pengertian lebih baik tentang dirinya, dapat menemukan konsep pada dirinya, menyatakan kebutuhannya-kebutuhannya, dan menyatakan reaksinya terhadap tekanan-tekanan terhadap dirinya. (Gerald Corey). Tujuan kegiatan ini adalah: a) bermain peran yang bertitik tolak dari permasalahan psikologis. Psikodrama digunakan untuk terapi, supaya anak dapat memperoleh pemahaman yang lebih baik tentang dirinya, menemukan konsep diri dan menyatakan reaksi terhadap tekanantekanan yang dialaminya, b) guna upaya pemecahan masalah psikis yang dialami oleh individu dan dituangkan dalam bentuk permainan peran dengan menggunakan metode drama. Manfaat dari kegiatan psikodrama antaralain: a) Menyadarkan potensi anak (insight) dan juga menggali (to explore) permasalahan/ perasaan yang sedang dihadapinya, b) Ikut merasakan perasaan dan mengetahui pikiran anak, c) Mengembangkan keberanian (spontanitas), kreativitas dan imajinasi anak. Langkahlangkah pengerjaan adalah sebagai berikut: a) Imajinasi kreatif (creative imagery), yaitu teknik pemanasan untuk mengundang anak membayangkan adegan dan objek yang menyenangkan dan netral. Teknik ini bertujuan untuk memunculkan spontanitas anak ketika diajak bermain peran. Tema yang dipilih adalah "Jenis Profesi di Masyarakat" yang dapat digunakan untuk mengangkat topik cita-cita anak. Waktu pelaksanaan pemanasan adalah selama 20-30 menit, b) Story-telling (dongeng), diharapkan melalui dongeng memiliki peran dan fungsi yang cukup penting dalam mendidik dan menyampaikan ajaran moral, namun juga bersifat menghibur. Dongeng diceritakan dengan alur yang sederhana, karakter dari tokoh tidak diceritakan secara rinci sehingga dapat memunculkan imajinasi anak. Untuk mengaitkan dengan tema jenis profesi maka yang dipilih adalah dongeng melalui tontonan film Smurfs "The Lost Village". Komponen kegiatan yang dibutuhkan adalah: a) Stage, area permainan yang cukup memberi ruang gerak bagi pemeran, b) Pemimpin Psikodrama / Terapist, sebagai sutradara, c) Pemeran, memilih peran secara spontan, memainkan kembali cerita, d) Penonton (audience), memberikan dukungan/feedback, dan e) Media: buku dongeng, wayang tokoh, perlengkapan profesi dan properti drama. Langkah-langkah pengerjaan adalah sebagai berikut: a) Persiapan (warming up). Pemimpin kelompok memberikan creative imagery dan cerita dongeng singkat, mengajak seluruh peserta untuk aktif menjadi pemeran dan menceritakan kembali dalam drama; b) Pentas (action). Pemeran 
dapat menvisualisasikan kembali cerita dengan pikiran, sikap dan perasaan yang tidak mereka sadari; c) Sharing dan Diskusi. Anak diberikan kesempatan untuk berpendapat mengenai pementasan yang telah dilakukan.

\section{HASIL DAN PEMBAHASAN}

Hasil dan pembahasan akan dipaparkan berdasarkan setiap sesi kegiatan:

\section{Sesi ke1: “Keberadaanku Saat Ini: Lingkungan Rumah Singgah YKAKI”}

Kegiatan ini diikuti oleh 7 orang anak penderita retinablastoma dan leukimia. Dari awal 15 orang anak yang direncanakan, 8 orang membatalkan partisipasinya karena kondisi kesehatan kurang memadai. Usia anak yang mengikuti bervariasi dari 2,5 tahun s.d. 11 tahun. Durasi pelaksanaan pun berubah dari yang direncanakan, semula 3 jam menjadi hanya 1,5 jam tanpa melakukan tahap presentasi. Hal ini karena beberapa anakanak pasien kanker tidak dalam kondisi baik. Proses menggambar figur orang (diri sendiri) memakan waktu cukup lama karena kebanyakan anak tidak percaya diri dan merasa tidak sanggup dalam menggambar orang. Namun demikian, tim pengabdi berupaya memancing dengan mengajak anak-anak mengobrol dan meminta mereka untuk menggambarkan secara bebas. Selanjutnya ketika disodorkan perangkat cat air, anakanak tampak lebih antusias. Demikian pula saat kegiatan membuat rumah dan menempelkan mebel di dalamnya, anak-anak terlihat lebih antusias. Dari situasi ini tampak bahwa media pensil kurang disukai oleh anak-anak ini. Gambar 1a, b, c berikut menunjukkan kegiatan yang telah dilaksanakan.
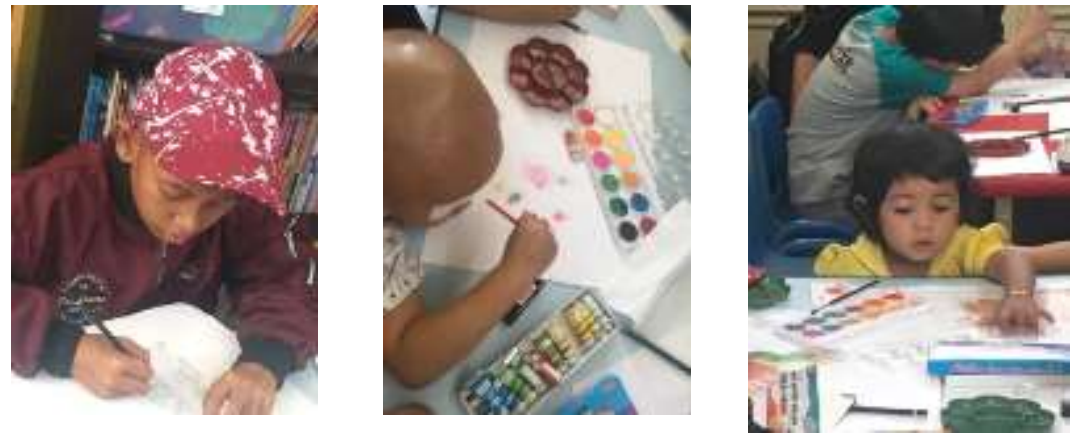

Gambar 1a, b, c. Proses kegiatan menggambar pasien anak dari berbagai usia

(Sumber: dokumentasi tim, 2019)

Anak-anak yang lebih kecil perlu dibantu dalam menggambarkan apa yang mereka inginkan dengan menyebutkan karakter bentuk, misalnya kepala bentuknya lingkaran, telinga berbentuk oval, dan sebagainya. Penggunaan tempelan kolase bendabenda cukup dapat membantu dalam penciptaan karya anak-anak yang kecil. Dalam proses berkreasi, anak-anak yang lebih muda usianya (di bawah 5 tahun) bersedia untuk mengomunikasikan apa yang digambarnya. Sementara anak-anak yang lebih besar (usia di atas 5 tahun) tampak sulit mengomunikasikan apa yang digambarnya. Seusai sesi menggambar, didapati bahwa kebanyakan peserta tidak mampu menyelesaikan gambarnya karena merasa letih. Berdasarkan hal ini disimpulkan bahwa sesi terapi seni ekspresif sebaiknya dilakukan dalam durasi pendek, yakni tidak lebih dari 1 jam. 


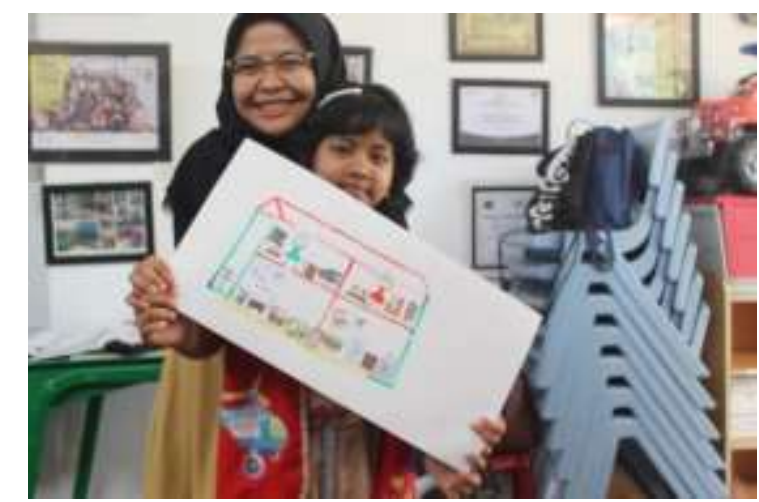

Gambar 2. Salah satu peserta dengan hasil karya ekspresif sesi ke-1 tentang lingkunganku saat ini (Sumber: dokumentasi tim, 2019)

\section{Sesi ke-2: Gambar "Harapan Di Hari Spesialku”}

Kegiatan ini hanya diikuti oleh 5 orang anak penderita retinablastoma dan leukimia. Pada saat ini banyak anak yang tidak berada di rumah singgah karena sedang ada jadwal terapi di RS. Proses menggambar cukup memakan waktu lama karena anakanak mengaku tidak punya ide bagaimana suatu perayaan itu dilaksanakan. Untuk membantu visualisasi, tim pengabdi berupaya memancing dengan mengajak anak-anak mengobrol tentang bagaimana perayaan ulang tahun atau hari raya dilakukan di rumah masing-masing. Sama seperti pada sesi 1 , tampak bahwa anak-anak kurang menyukai media pensil dan spidol. Kegiatan ini pada akhirnya lebih berupa sesi mengobrol dan bercanda pada saat memancing anak-anak untuk mengingat hal-hal yang membahagiakan, objek-objek yang ingin mereka peroleh dan membuat mereka gembira. Gambar 3a, b, dan c berikut menunjukkan foto-foto kegiatan yang telah dilaksanakan:

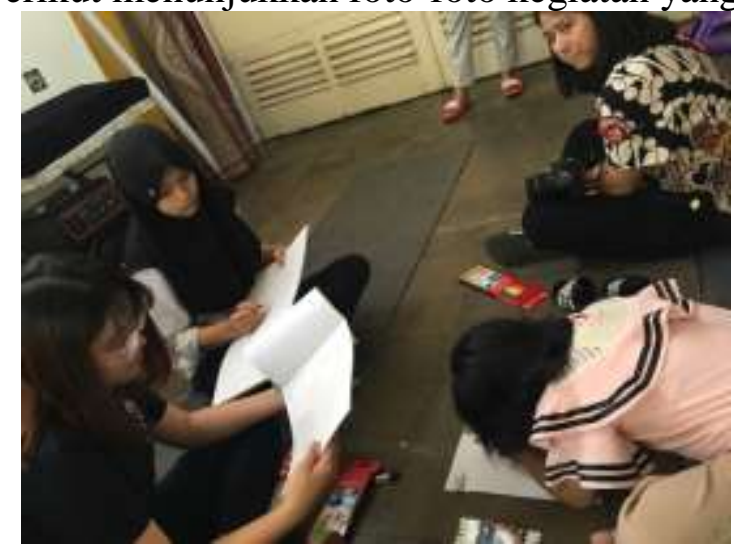



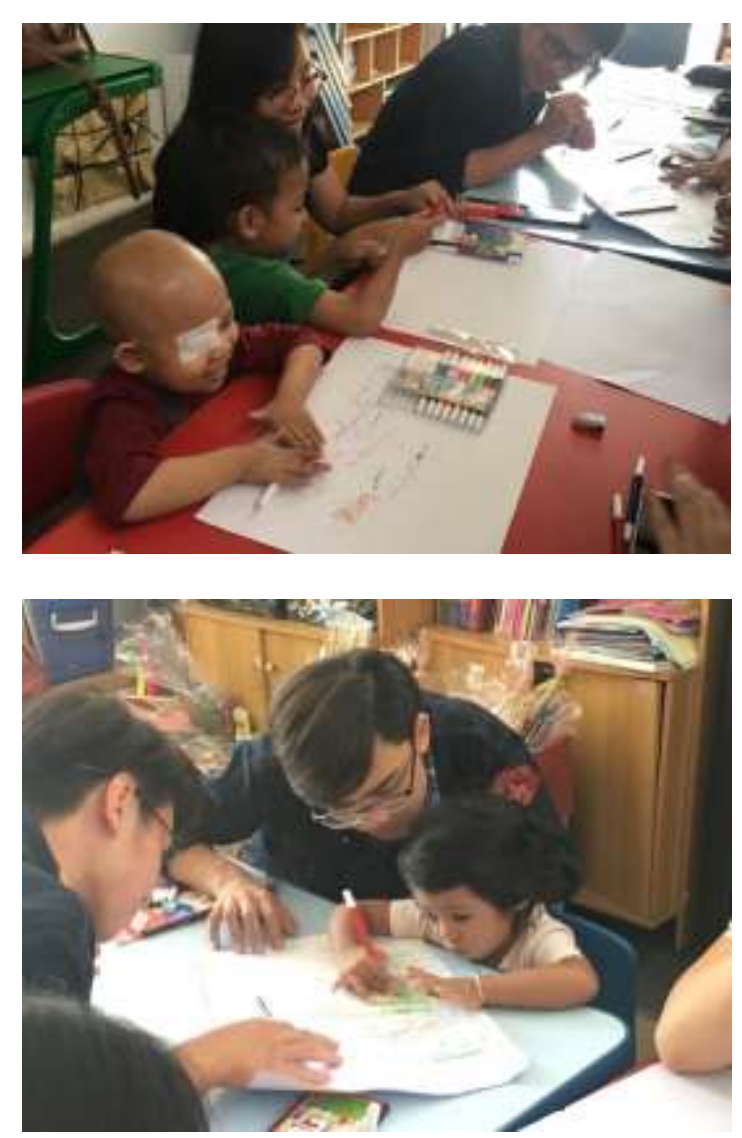

Gambar 3a, b, c. Situasi bebas dan santai saat anak menggambar ekspresif sambil diajak untuk bercerita oleh tim pengabdi (Sumber: dokumentasi tim, 2019)

Dari sesi 1 dan 2, didapati bahwa proses bercerita pada anak yang dilakukan sambil menggambar lebih efektif daripada anak diminta melakukan presentasi di akhir sesi. Diketahui pula bahwa saat bercerita sambil menggambar, anak lebih rileks, antusias, dan ekspresif dibandingkan dengan jika diminta untuk presentasi di akhir sesi. Dalam hal ini, tim pengabdi membebaskan anak-anak untuk berekspresi sesuai dengan kesukaan dan kemampuannya sendiri untuk mengekspresikan diri sebagaimana yang diinginkannya. Paulo Freire menyebutkan bahwa melalui penciptaan praksis (aksi dan refleksi) maka akan menjamin pembelajaran kritis yang lebih efektif (Silviana \& Sayekti, 2018). Di sisi lain, pasien kanker memiliki pilihan terbatas tentang apa yang dapat mereka lakukan setiap hari Oleh karena itu, penting bagi mereka untuk memiliki rasa pengendalian diri (Councill \& Ramsey, 2019). Dengan memilih bagaimana pasien kanker melakukan aktivitas seni ekspresif yang mereka inginkan, serta alat dan media yang akan digunakan maka akan terwujud perasaan bahwa mereka dapat mengendalikan apa yang terjadi terhadap diri mereka (Setyoningrum et al., 2020).

\section{Sesi 3. Gambar "Psikodrama Cita-Citaku"}

Kegiatan ini diikuti oleh paling banyak peserta, yaitu 19 orang anak pasien kanker berusia antara 2,5 tahun hingga 16 tahun. Anak-anak lebih antusias karena sesi ini diawali dengan sesi menonton film Smurf. Selanjutnya sesi psikodrama hanya efektif dilakukan 
oleh anak-anak yang berusia lebih kecil, sementara itu anak-anak yang lebih besar lebih malu-malu untuk tampil. Kegiatan diselingi dengan menyanyi bersama dan anak-anak mencoba performance tari yang telah mereka latih untuk suatu acara. Dari kegiatan psikodrama ini anak-anak diajak untuk berkhayal dan memiliki harapan pada masa depan mereka melalui peragaan gerak simbolik. Hasil yang diperoleh anak-anak tampak bersemangat membayangkan diri mereka menjadi penyanyi dan bintang film dengan memperagakan kegiatan berdandan/mengenakan make-up, lalu menjadi polisi dengan memperagakan kegiatan mengatur lalu lintas melalui gerakan tangan dan meniup peluit. Namun profesi yang paling disukai oleh anak-anak adalah menjadi dokter. Ketika satu orang mengambil peran sebagai dokter, beberapa anak lain mengungkapkan keinginan yang sama. Selanjutnya alur kegiatan berkembang menjadi semakin seru, ketika beberapa anak berperan menjadi dokter, perawat, dan lainnya sebagai pasien. Permainan peran yang mereka sukai adalah kegiatan mengantre kunjungan ke dokter, melakukan percakapan konsultasi kesehatan dan menyuntik. Anak-anak tampak fasih saat memperagakan prosedur menyuntik, berbeda dengan peragaan profesi lainnya yang terlihat ragu-ragu. Interaksi yang dilakukan oleh anak-anak menunjukkan aspek emosional yang positif sebagai refleksi dari aktivitas pengobatan mereka sehari-hari. Hal ini tampak dari simulasi kalimat hiburan yang diucapkan agar pasien yang disuntik tidak takut, seruan agar pasien mengantre dengan tertib dan sabar.
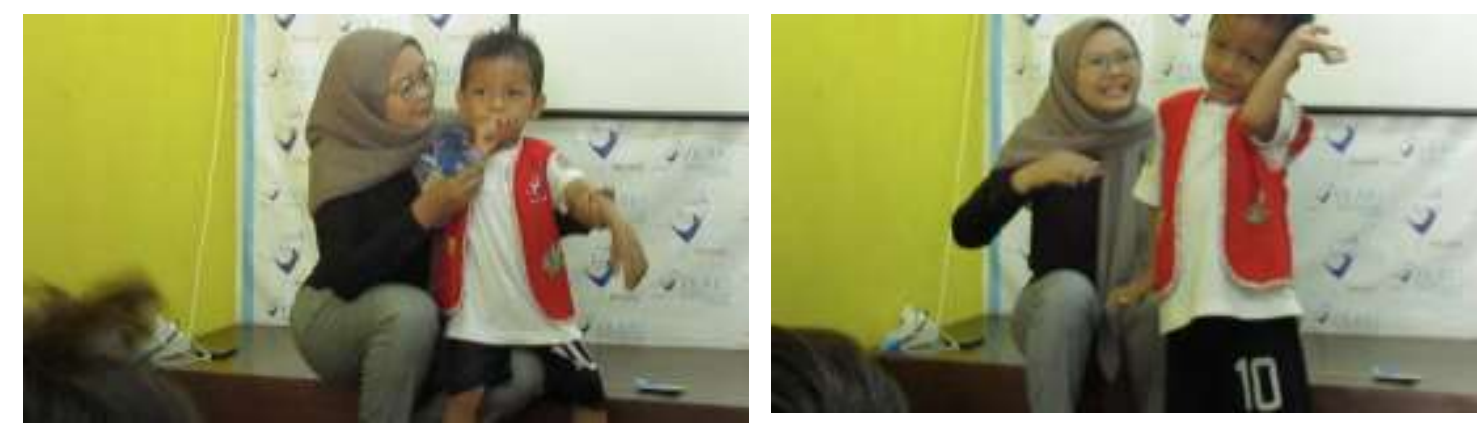

Gambar 4a, b. Salah seorang peserta memperagakan peran polisi (Sumber: dokumentasi tim, 2019)
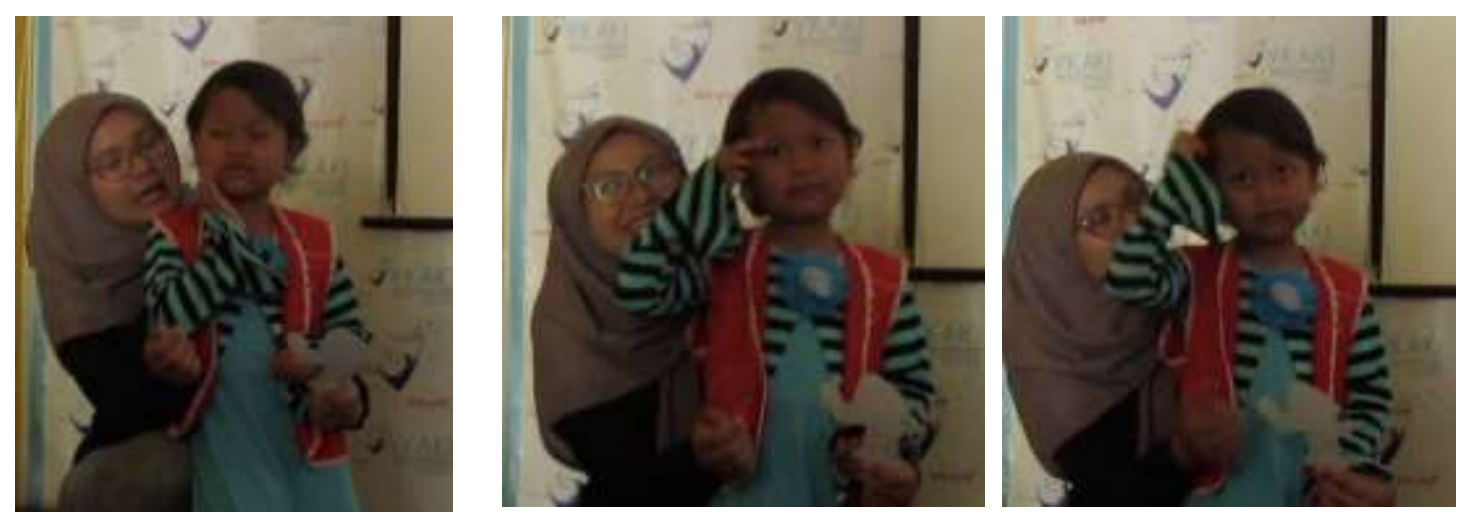

Gambar 5a, b, c. Salah seorang peserta memperagakan peran bintang film yang sedang berdandan (Sumber: dokumentasi tim, 2019) 


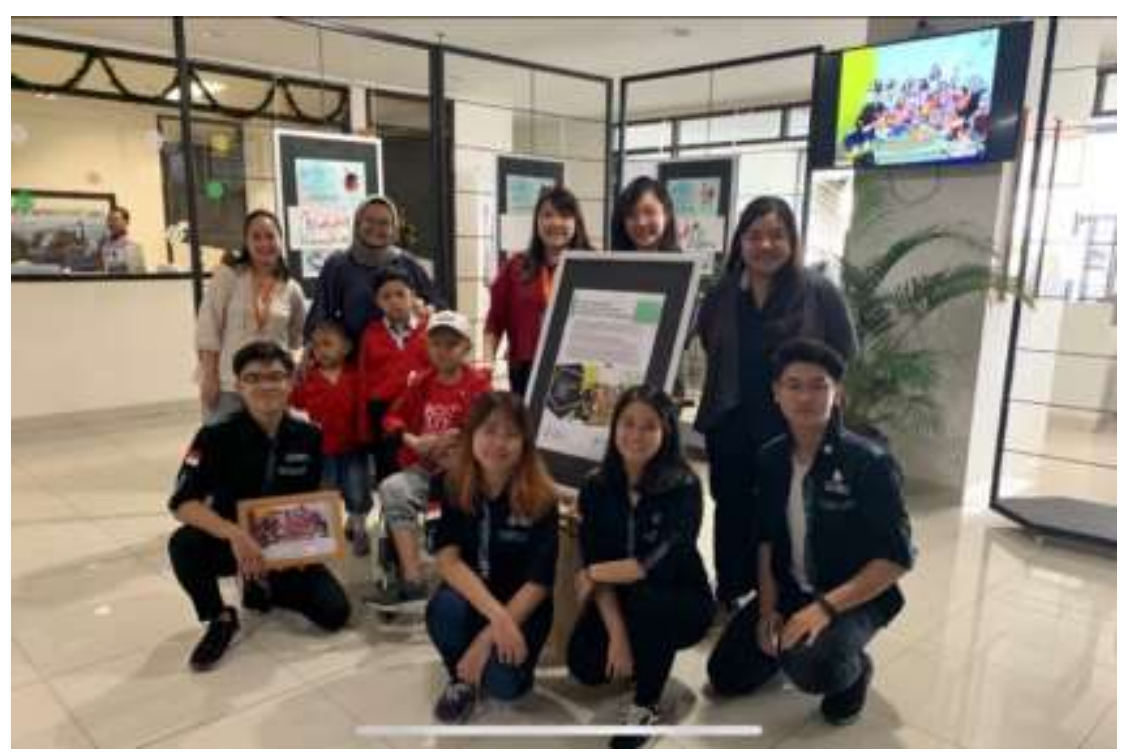

Gambar 6. Pameran hasil karya dan dokumentasi terapi seni ekspresif (Sumber: dokumentasi tim, 2019)

\section{PENUTUP}

Melalui kegiatan terapi seni ekspresif ini dapat diketahui bahwa anak-anak yang berada di rumah singgah sungguh membutuhkan aktivitas edukatif konstruktif yang dapat dilakukan dalam durasi singkat, termasuk dalam hal ini aktivitas seni rupa yang dikemas seperti suasana bermain. Hal ini disebabkan karena semua anak yang berada disini putus sekolah. Beberapa anak dapat mengurus penyetaraan nilai dengan sekolah di tempat asalnya, namun kebanyakan akhirnya tidak bersekolah. Saran untuk kegiatan terapi seni selanjutnya perlu dipertimbangkan beberapa hal teknis seperti: a) Durasi pelaksanaan yang singkat. Anak-anak pasien kanker cepat lelah sehingga aktivitas sebaiknya dibatasi maksimal 1 jam per sesi; b) Diskusi/sesi mengobrol one on one antara anak dan terapis amat baik apabila dapat terus dilaksanakan sambil mengerjakan satu project karya; c) Penggunaan media dan alat gambar yang mudah diaplikasikan dengan hasil/tampilan yang kontras/tajam. Pensil atau spidol sebaiknya diganti dengan penggunaan cat; d) Penggunaan ilustrasi atau simulasi media elektronik digital sangat disarankan untuk menstimulasi ide dan kreasi di awal project karya karena lebih mudah diserap dan dipahami oleh anak-anak.

\section{DAFTAR PUSTAKA}

Alysa Stivanie Kania Damanik. (2015). PSIKODRAMA UNTUK MENURUNKAN TINGKAT STRES PADA SISWA AKSELERASI. 03, 18.

Bozcuk, H., Ozcan, K., Erdogan, C., Mutlu, H., Demir, M., \& Coskun, S. (2017). A comparative study of art therapy in cancer patients receiving chemotherapy and improvement in quality of life by watercolor painting. Complementary Therapies in Medicine, 30, 67-72. https://doi.org/10.1016/j.ctim.2016.11.006

Councill, T. D., \& Ramsey, K. (2019). Art Therapy as a Psychosocial Support in a Child's Palliative Care. Art Therapy, 36(1), 40-45. https://doi.org/10.1080/07421656.2019.1564644 
Loita, A. (2017). Karakteristik Pola Gambar Anak Usia Dini. Early Childhood: Jurnal Pendidikan, 1(1), 44-57. https://doi.org/10.35568/earlychildhood.v1i1.52

Reynolds, F., \& Lim, K. H. (2007). Contribution of visual art-making to the subjective well-being of women living with cancer: A qualitative study. The Arts in Psychotherapy, 34(1), 1-10. https://doi.org/10.1016/j.aip.2006.09.005

Robert D. Clements, Frank Wachowiak. (2010). Emphasis Art: A Qualitative Art Program for Elementary and Middle Schools MyEducationLab Series (9th, illustrated ed.). Allyn \& Bacon.

Setyoningrum, Y., Suhanjoyo, S. N., \& Muliati, A. (2020). Methods and Timeframe Benefits of Art Therapy on Cancer Patients. Proceedings of the 2nd International Conference on Arts and Design Education (ICADE 2019). 2nd International Conference on Arts and Design Education (ICADE 2019), Lembang, Indonesia. https://doi.org/10.2991/assehr.k.200321.019

Silviana, I., \& Sayekti, F. P. (2018). Bermain Dan Berinteraksi Dengan American Natives Sebagai Metode Belajar Anak Di Kediri, Jawa Timur. Dinamisia: Jurnal Pengabdian Kepada Masyarakat, 2(2), 229-235. Https://Doi.Org/10.31849/Dinamisia.V2i2.1163

Singh, B. (2011). The therapeutic effects of art making in patients with cancer. The Arts in Psychotherapy, 38(3), 160-163. https://doi.org/10.1016/j.aip.2011.04.001

Robert D. Clements, Frank Wachowiak. (2010). Emphasis Art: A Qualitative Art Program for Elementary and Middle Schools MyEducationLab Series (9th, illustrated ed.). Allyn \& Bacon. 
AKSARA: Jurnalllmu Pendidikan Nonformal

P-ISSN 2407-8018 E-ISSN 2721-7310 DOI prefix 10.37905

Volume 07, (03) September 2021

http://ejurnal.pps.ung.ac.id/index.php/Aksara 